\section{Diverse Responses of Lettuce Cultivars and Germplasm Lines to Infections of Three Isolates of Xanthomonas campestris pv. vitians}

\author{
Yunwen Wang, Huangjun Lu ${ }^{2}$, Richard N. Raid, Gregg S. Nuessly, \\ and Georgy Faroutine ${ }^{1}$ \\ Everglades Research and Education Center, University of Florida/Institute \\ of Food and Agricultural Sciences, Belle Glade, FL 33430
}

Additional index words. lettuce, Xanthomonas campestris pv. vitians, isolate, disease incidence, disease severity, disease resistance

\begin{abstract}
Bacterial leaf spot (BLS) disease, caused by Xanthomonas campestris pv. vitians $(X c v)$ has become an increasingly damaging disease in the lettuce production areas of the United States. To understand the nature of the outbreaks of this disease, the pathogenic variations for causing disease were evaluated on 29 lettuce cultivars and germplasm lines using three $\mathrm{Xcv}$ isolates recovered in different years from the Everglades Agriculture Area (EAA) of Florida. Significant differences were shown in both the BLS incidences and disease severities among the three $X c v$ isolates, and the rank from high virulence to less severity was L7 > JF196 > NF1. Our results suggest that the pathogenic variations of the isolates may have been associated with the epidemic outbreaks of BLS in EAA. Among the 29 lettuce genotypes, the host plant resistance was characterized by specific host genotype and $X c v$ isolate interactions. The leaf lettuce PI358001-1 was consistently in the high resistant category to all three $X c v$ isolates, and is a promising resistant source for development of resistant cultivars.
\end{abstract}

Lettuce (Lactuca sativa L.) is one of the top ten most valuable crops in the United States with an average annual value of \$2.1 billion (USDA, 2014). There are eight types of lettuce grown in the world, whereas four of them including crisphead, butterhead, romaine, and leaf are the major market types in the United States. On average from a 5-year data (2009 through 2013), head, romaine, and leaf lettuce accounted for $55.0 \%, 30.7 \%$, and $14.3 \%$ of the U.S. lettuce production, respectively (USDA, 2014). California and Arizona are the two largest growing states of lettuce, producing $96 \%$ of head and romaine lettuce, and $98 \%$ of leaf lettuce in the United States (Glaser et al., 2001). Lettuce is an important winter vegetable crop in Florida. The EAA is the main production area of the state with an annual acreage of $10,000-11,000$ and a farm gate value of $\$ 50$ $\$ 60$ millions. The warm and humid subtropical climate in Florida favors occurrence of biotic

\footnotetext{
Received for publication 18 Feb. 2015. Accepted for publication $26 \mathrm{Feb} .2015$.

This work was supported by grants from Florida Specialty Crop Block Grant Program, USDA (grant no. 00114165) and the CRIS project (project no. FLA-BGL-005105) to H. Lu. We thank Dr. Joubert Fayette for providing the $\mathrm{Xcv}$ isolate JF196 for the research. We also thank Dr. Soumaila Sanogo at New Mexico State University for helping to train Y. Wang before he started this study.

${ }^{1}$ Former undergraduate student intern from Earth University in Costa Rica.

${ }^{2}$ To whom reprint requests should be addressed; e-mail hjlu@ufl.edu.
}

stresses such as diseases, which have significant, adverse impacts on lettuce production.

Bacterial leaf spot (BLS), caused by $X c v$, is a devastating disease of lettuce in Florida. This disease was first reported in South Carolina and Virginia in the United States in 1918 (Brown, 1918). Since 1990s, substantial outbreaks of BLS have been reported with increasing frequency in some of the major lettuce growing regions, such as California (Barak et al., 2001; Bull et al., 2007; Bull and Koike, 2005; Umesh et al., 1996), Florida (Lu and Raid, 2013; Pernezny et al., 1995), and Ohio (Sahin and Miller, 1997). Currently, there are no chemicals available to control the disease. A severe epidemic usually results in significant crop damage and economic losses.

Initial symptoms of BLS occur on mature, outer leaves with small water-soaked angular leaf lesions, and later become brown to black necrotic and papery (Koike and Gilbertson, 1997). The symptoms then spread to other parts of the lettuce plants, resulting in unmarketable heads or hearts. Epidemiology of the disease has been investigated on a number of factors associated with dispersal and survival of $X c v$. The pathogen is thought to be seedborne and can survive on dry seeds for extended periods (Sahin and Miller, 1997). $X c v$ can be transmitted by lettuce plant debris in soil or leaves of symptomless weed species after the summer and winter fallow periods in California (Barak et al., 2001). Xcv has also been demonstrated to be spread rapidly by overhead irrigation in greenhouse from only a few infected plants (Toussaint, 1999). A broad list of potential host plant species has been provided after inoculation of these plants with $X c v$ (Tsuchiya et al., 1981). Robinson et al. (2006) identified pepper as a potential crop host of $X c v$ of lettuce in Florida and also determined that the optimum temperature for $X c v$ infection is $22.7^{\circ} \mathrm{C}$ under growth chamber conditions.

Nevertheless, virulence diversity of $\mathrm{Xcv}$ strains and variation of host responses among lettuce genotypes are very important epidemiological aspects for understanding and controlling BLS outbreaks. Structure differences of DNA, RNA, and other biochemical factors among $X c v$ strains have been investigated (Barak and Gilbertson, 2003; Sahin et al., 2003). Pernezny et al. (1995) found that symptoms in plants inoculated with the five Florida strains individually were more severe than other three $X c v$ reference strains from outside of the state, whereas, although the three lettuce genotypes tested were susceptible to $X c v$, the disease reactions of crisphead cv. South Bay was less severe than romaine cv. Tall Guzmaine and butterhead breeding line B-1190. Different levels of host resistance have been reported in commercial lettuce cultivars or germplasm by inoculation with single $X c v$ strain (Carisse et al., 2000; Lu and Raid, 2013; Pernezny et al., 2000) or a mixture of $X c v$ strains (Bull et al., 2007; Hayes et al., 2014; Sahin and Miller, 1997). However, information is limited on responses of resistant lettuce genotypes to different $X c v$ strains. In addition, there have been no reports on change of pathogenic virulence of $X c v$ strains recovered in severe epidemic years and nonepidemic years in the same region.

The objectives of this study were to 1) investigate pathogenic differences of $X c v$ strains isolated in various years in the EAA of Florida with BLS outbreaks or without a severe disease occurrence and 2) determine reactions of susceptible and resistant lettuce genotypes to the different $X c v$ strains.

\section{Materials and Methods}

Pathogenicity tests were conducted according to the method reported by $\mathrm{Lu}$ and Raid (2013). The tests were repeated twice. For the first trial, seeds were sown on 2 Oct. 2014, seedlings were inoculated with three $\mathrm{Xcv}$ isolates on 30 Oct. 2014, and plants were scored on 17 Nov. 2014. For the second trial, seeds were sown on 8 Oct. 2014, seedlings were inoculated on 5 Nov. 2014, and plants were scored on 24 Nov. 2014. The experiment design was a split-plot design with $X c v$ isolate being main plots and lettuce genotypes being subplots and had three replications.

Plant materials. A total of 30 lettuce genotypes consisting of 10 crisphead, 13 romaine, 4 butterhead, 2 leaf, and 1 latin lettuce as a resistant control were used for pathogenicity evaluation (Table 1). Seeds of each genotype were sown in a single row with 10 rows for 10 genotypes in a $30 \times 50 \mathrm{~cm}$ flat tray filled with Fafard growing mix containing $65.75 \%$ Canadian sphagnum peat, moss, perlite, and composted tree bark (Sun Gro 
Horticulture, Agawam, MA) at University of Florida/IFAS Everglades Research and Education Center, Belle Glade, FL, which is located on the EAA in the state. The 30 genotypes were randomly planted in three flat trays for each replication for each $\mathrm{Xcv}$ isolate and $5 \mathrm{~g}$ controlled release fertilizer 14 $\mathrm{N}-14 \mathrm{P}_{2} \mathrm{O}_{5}-14 \mathrm{~K}_{2} \mathrm{O}$ (Osmocote Classic, The Scotts Co., Marysville, $\mathrm{OH}$ ) was applied by broadcasting to each flat tray. The flat trays were watered and then placed on a bench outside a greenhouse to receive full sunlight with an automatically mist irrigation supply for 10 min each day. At 2-3 leaf stage, plants were thinned to 10 plants per row. Because of low seed germination, not enough plants of PI274373-1 were established and this genotype was excluded for further evaluation.

Bacterial isolates, inoculum preparation, and inoculation. All three isolates of $X c v$ used in the study were recovered from commercial lettuce fields in Belle Glade, FL. Among them, strain L7 was originally isolated by Pernezny et al. (1995) in 1993, JF196 was isolated by Fayette (2014) in 2012, and NF1 was isolated by us in 2014. Stock cultures of the three $\mathrm{XcV}$ isolates were stored in $15 \%$ sterile glycerol solution at $-20{ }^{\circ} \mathrm{C}$. Bacterial colonies of the isolates were recovered from stock cultures by streaking on yeast dextrose carbonate (YDC) agar. The plates were incubated for growth for $3 \mathrm{~d}$ at $28^{\circ} \mathrm{C}$.

Single colony of each isolate was then picked and transferred into six 500-mL flasks with $350 \mathrm{~mL}$ nutrient broth (NB; Difco Laboratories, Detroit, MI). The isolates were grown on a shaker at $200 \mathrm{rpm}$ for $60 \mathrm{~h}$ at room temperature. Cultures were centrifuged at $7000 \mathrm{rpm}$ for $5 \mathrm{~min}$, the supernatant was discarded, and the bacterial pellets were resuspended in $15 \mathrm{~mL}$ sterile buffered saline (Leben et al., 1968). The same bacterial isolate suspensions from six flasks were combined into one suspension, and its concentration was confirmed by the dilution plating method. Suspensions of each isolate were kept for less than $3 \mathrm{~d}$ at $4{ }^{\circ} \mathrm{C}$ before inoculation. Before inoculation, bacterial suspension of each isolate was adjusted to $\approx 1 \times 10^{8}$ colony-forming units $(\mathrm{cfu}) / \mathrm{mL}$ with sterile deionized (DI) water, and $60 \mu \mathrm{L}$ sterile Tween 20 was added to $100 \mathrm{~mL}$ solutions.

At the six- to eight-leaf stage, plants in each tray were inoculated by inoculums by misting plant leaves to runoff using a handheld sprayer at a rate of $\approx 100 \mathrm{~mL}$ for each tray in laboratory. Immediately following inoculation, all three trays of each replicate for the same $X c v$ isolate were placed into a new polyethylene bag, enclosed, and kept at room temperature in dark for $48 \mathrm{~h}$. The plants were then removed from the bags and grown in a greenhouse where temperature was maintained between 20 and $28{ }^{\circ} \mathrm{C}$ for 2 weeks. Plants were sprinkle-irrigated two times a day, once in the morning at 8:00 and in the afternoon at 1:00, respectively, to encourage disease development. After 2 weeks, plants were scored for disease incidence and severity. The disease incidence was calculated by the percent of infected plant among all plants in each row. The disease severity of a plant was evaluated using the $0-4$ rating system as reported by Bull et al. (2007) with modifications: $0=$ no symptoms, $1=$ one to 10 lesions with each diameter less than $3 \mathrm{~mm}, 2=$ more than 10 lesions with each diameter less than 3 $\mathrm{mm}, 3=$ lesions of which diameter larger than $3 \mathrm{~mm}$, and $4=$ coalesced lesions. In each row, the average disease severity value was calculated from five random plants. Genotypes with an average score of 0 to 0.9 for disease severity were classified as highly resistant, 1.0 to 1.9 was moderately resistant, 2.0 to 2.9 as moderately susceptible, and higher than 3.0 as susceptible.

Data analysis. Data were analyzed using SAS software (SAS/Stat procedures, Version 9.3; SAS Institute, Inc., Cary, NC). Analysis of variance (ANOVA) using the PROC GLM command in SAS was conducted to calculate the effects of trials, lettuce genotypes and $\mathrm{XcV}$ isolates on BLS disease incidence and severity. Data on disease incidences (\%) were transformed by arcsine square root before ANOVA. Least significant difference method at the $5 \%$ significant level was used for multiple comparisons for disease incidence and severity among 29 genotypes in each trial within each of the three $X c v$ isolates and also among three $X c v$ isolates in each trial.

\section{Results and Discussion}

Pathogenicity difference among Xcv isolates. Significantly different BLS incidence and severity were observed among three $\mathrm{Xcv}$ isolates which were collected in different years in EAA, Florida (Table 2). Variances of interactions between trial and $\mathrm{Xcv}$ isolate and between genotype and $\mathrm{Xcv}$ isolate were also significant for both BLS incidence and severity rate, whereas variance of trial $\times$ genotype $\times X c v$ isolate interactions was significant only for the BLS incidence (Table 2). Based on overall means of 29 genotypes, L7 was the most virulent $X c v$ isolate, causing symptoms on $81.1 \%$ of plants in trial 1 and $87.6 \%$ of plants in trial 2 (Table 3). Plants had an average disease severity of 1.75 in trial 1 and an average disease severity of 2.91 in trial 2 . Disease incidences were $69.0 \%$ in trial 1 and $74.0 \%$ in trial 2 and disease severities were 1.16 and

Table 1. Lettuce genotypes used for pathogenicity evaluation.

\begin{tabular}{llll}
\hline Serial No. & Cultivar name & Horticultural type & \\
\hline 1 & 10157 & Romaine & This study \\
2 & 10160 & Crisphead & This study \\
3 & 10168 & Romaine & This study \\
4 & 10176 & Romaine & This study \\
5 & 10178 & Romaine & This study \\
6 & 50100 & Romaine & This study \\
7 & 50664 & Crisphead & This study \\
8 & 60157 & Crisphead & This study \\
9 & 60167 & Crisphead & This study \\
10 & 60182 & Romaine & This study \\
11 & 60185 & Romaine & This study \\
12 & 70096 & Romaine & This study \\
13 & 8074 & Crisphead & GMI (unpublished data) \\
14 & 9085 & Crisphead & GMI (unpublished data) \\
15 & Floricos83 & Romaine & Guzman and Zitter (1983) \\
16 & Gator & Crisphead & Seminis Vegetable Seeds, Inc. (USDA, 2015a) \\
17 & Glades & Romaine & 3 Star Lettuce, LLC (USDA, 2015a) \\
18 & h1078 & Crisphead & unknown \\
19 & Lantana & Crisphead & 3 Star Lettuce, LLC (USDA, 2015a) \\
20 & Little Gem & Latin & Burpee Gardens (USDA, 2015b) \\
21 & Manatee & Romaine & 3 Star Lettuce, LLC (USDA, 2015a) \\
22 & Okeechobee & Romaine & 3 Star Lettuce, LLC (USDA, 2015a) \\
23 & PI274373-1 & Butterhead & USDA-ARS germplasm collection (USDA, 2015c) \\
24 & PI289016-2 & Leaf & USDA-ARS germplasm collection (USDA, 2015c) \\
25 & PI289025-1 & Butterhead & USDA-ARS germplasm collection (USDA, 2015c) \\
26 & PI342512-1 & Butterhead & USDA-ARS germplasm collection (USDA, 2015c) \\
27 & PI342532-1 & Butterhead & USDA-ARS germplasm collection (USDA, 2015c) \\
28 & Raleigh & Crisphead & Guzman (1984) \\
29 & Terrapin & Romaine & Seminis Vegetable Seeds-Genecorp (USDA, 2015b) \\
30 & PI358001-1 & Leaf & USDA-ARS germplasm collection (USDA, 2015c) \\
\hline & & &
\end{tabular}

Table 2. Analysis of variance for 29 lettuce genotypes infected with three isolates of Xanthomonas campestris pv. viticans in two trials.

\begin{tabular}{|c|c|c|c|c|c|c|c|}
\hline \multirow[b]{2}{*}{ Source } & \multirow[b]{2}{*}{$\mathrm{DF}$} & \multicolumn{3}{|c|}{ Disease incidence (\%) } & \multicolumn{3}{|c|}{ Severity rate (Scale $0-4$ ) } \\
\hline & & Mean Square & F value & $\overline{\operatorname{Pr}>F}$ & $\overline{\text { Mean Square }}$ & F value & $\overline{\operatorname{Pr}>F}$ \\
\hline Trial (T) & 1 & $7,235.58$ & 36.51 & $<0.0001$ & 64.91 & 194.78 & $<0.0001$ \\
\hline $\operatorname{Rep} / \mathrm{T}$ & 1 & 296.43 & 1.50 & 0.2230 & 0.61 & 1.84 & 0.1762 \\
\hline Isolate (I) & 2 & $28,964.19$ & 146.14 & $<0.0001$ & 55.50 & 166.55 & $<0.0001$ \\
\hline Genotype (G) & 28 & $3,033.05$ & 15.30 & $<0.0001$ & 3.53 & 10.60 & $<0.0001$ \\
\hline $\mathrm{T} \times \mathrm{I}$ & 2 & $1,029.48$ & 5.19 & 0.0065 & 1.90 & 5.70 & 0.0040 \\
\hline $\mathrm{T} \times \mathrm{G}$ & 28 & 353.59 & 1.78 & 0.0136 & 0.99 & 2.99 & $<0.0001$ \\
\hline $\mathrm{G} \times \mathrm{I}$ & 56 & 419.22 & 2.12 & 0.0001 & 0.64 & 1.93 & 0.0007 \\
\hline $\mathrm{T} \times \mathrm{G} \times \mathrm{I}$ & 56 & 432.83 & 2.18 & $<0.0001$ & 0.32 & 0.96 & 0.5649 \\
\hline Error & 170 & 198.19 & & & 0.33 & & \\
\hline
\end{tabular}


Table 3. Average disease incidences and severities of 29 lettuce genotypes infected with three isolates of Xanthomonas campestris pv. viticans in two repeated trails.

\begin{tabular}{|c|c|c|c|c|}
\hline \multirow[b]{2}{*}{ Isolate } & \multicolumn{2}{|l|}{ Trial 1} & \multicolumn{2}{|l|}{ Trial 2} \\
\hline & $\begin{array}{l}\text { Disease incidence }(\%, \text { then } \\
\text { transformed by arcsine } \\
\text { square root })\end{array}$ & $\begin{array}{l}\text { Disease severity } \\
\text { (scale } 0-4)\end{array}$ & $\begin{array}{l}\text { Disease incidence }(\%, \text { then } \\
\text { transformed by arcsine } \\
\text { square root })\end{array}$ & $\begin{array}{l}\text { Disease severity } \\
\quad \text { (scale } 0-4)\end{array}$ \\
\hline$\overline{\text { JF196 }}$ & $60.55 \mathrm{~b}^{\mathrm{x}}[69.03]^{\mathrm{w}}$ & $1.16 \mathrm{~b}$ & $65.45 \mathrm{~b}$ [74.03] & $1.94 \mathrm{~b}$ \\
\hline L7 & $71.28 \mathrm{a}[81.11]$ & $1.75 \mathrm{a}$ & 77.96 a [87.65] & $2.91 \mathrm{a}$ \\
\hline NF1 & 35.17 c [36.49] & $0.62 \mathrm{c}$ & 50.98 c [57.97] & $1.27 \mathrm{c}$ \\
\hline
\end{tabular}

${ }^{\mathrm{z} D i s e a s e}$ incidence was expressed as percentage of plants exhibiting infection.

y Disease severity was evaluated using the rating system as described in Bull et al. (2007) with modifications: $0=$ no symptoms on a plant; $1=1-10$ lesions of less than $3 \mathrm{~mm} ; 2=$ more than 10 lesions of less than $3 \mathrm{~mm} ; 3=$ lesions of greater than $3 \mathrm{~mm}$; and $4=$ coalesced lesions.

${ }^{\mathrm{x}}$ Means in the column followed by the same letter are not significantly different $(a=0.05)$ using a least significant difference test (Version 9.3; SAS Institute, Cary, NC).

${ }^{w}$ Data in the parenthesis were the original average values.

1.94 in the two trials when plants were inoculated with $X c v$ isolate JF196. The $X c v$ isolate NF1 caused symptoms on $36.5 \%$ of plants with an average disease severity of 0.62 in trial 1 and $57.9 \%$ of plants with a disease severity of 1.27 . Therefore, L7 was the most virulent $X c v$ isolate to lettuce and NF1 was the least virulent isolate. This indicated that there were pathogenic differences among the $X c v$ isolates collected from EAA. Our results were in accordance with those of Sahin et al. (2003) and Barak and Gilbertson (2003). Sahin et al. (2003) tested $44 \mathrm{Xcv}$ strains on a susceptible romaine type lettuce cv. Darkland and conducted biochemical and molecular tests. They found that the $X c v$ strains could be divided into two distinct groups based on the pathogenic variation and structure diversity. Genetic diversity was measured among $48 \mathrm{Xcv}$ strains preliminarily recovered in California in 1990s through pathogenic testing on a susceptible crisphead type lettuce cv. Salinas, and through analyses of the restriction fragment length polymorphisms (RFLPs) and plasmid DNA probe (Barak and Gilbertson, 2003). The genetic variability existed not only among strains from different geographical regions, but also among strains from the same location. The authors demonstrated that the population structure of $X c v$ strains were not clonal, but composed of relatively homogeneous groups.

The three $\mathrm{XcV}$ isolates were recovered from the fields in EAA area in different years when there were different levels of BLS outbreaks. The $X c v$ isolate $\mathrm{L} 7$ was recovered from lettuce samples with BLS symptoms in 1993 when a severe BLS outbreak occurred. JF196 was isolated from lettuce leaf samples with viable BLS disease symptoms in late season of 2012 when the lettuce production was already finished. NF1 was recovered from lettuce samples in a field with a minor outbreak in Feb. 2014, which was in the middle season of lettuce production in EAA, FL. Our results suggested that much virulent $X c v$ pathogen (L7) may have led to the severe BLS epidemic in 1993. On the contrary, NF1 was the least virulent isolate and only caused light disease (disease severity 0.62 in trial 1 and 1.27 in trial 2), which was probably the main reason why the disease occurring in the middle season (Feb. 2014) did not spread to other lettuce fields to cause an extensive outbreak. However, it is not known what has caused significantly different pathogenicity in the same location. Because $X c v$ can be seedborne, infested seed transmission from different geographic regions could have resulted in change of strains in EAA. Genetic exchanges between different $X c v$ strains, other pathovars and species, and mutation in $X c v$ were also possible. Using RFLP markers, high genetic diversity of the cassava (Manihot eaculenta Crantz) bacterial pathogen Xanthomonas axonopodis pv. manihotis strains were detected within most of the field samples in less than one year, and significant changes of strain genotypes in pathogen population occurred during a single crop cycle (Restrepo et al., 2004). Pathogen races of $X$. a. pv. vesicatoria changed within a season in pepper fields (Kousik and Ritchie, 1996; Vauterin et al., 1996). Host ranges and environmental factors such as rainfall and temperature may also have a critical influence on the strain shifts (Scortichini, 2005).

Responses of lettuce genotypes to different $\mathrm{Xcv}$ isolates. A wide range of susceptible and resistant lettuce genotypes representing five horticultural types were tested in this study. Significant differences of BLS incidence and severity rate were observed among the 29 genotypes (Table 2 ). In addition to the interaction effects of genotype $\times X c v$ isolate and trial $\times$ genotype $\times X c v$ isolate described previously, trial $\times$ genotype interaction was significant for the BLS incidence and severity rate (Table 2). Disease incidence percent and severity rate generally were higher in the second trial than the first one, indicating that the plants and environmental factors in the second trial were more favorable for infection of $X c v$ and for disease development. Differences in disease occurrences between two repeated trials have been previously observed in the greenhouse studies (Pernezny et al., 2000) and in the field evaluations (Bull et al., 2007). Taken overall results of plant disease incidence percent and severity rate for individual genotypes in the two trials (Figs. 1 and 2), leaf lettuce 'PI358001-1' expressed the highest resistance to all three $X c v$ isolates, having disease incidence $18 \%$ and disease severity 0.3 in trial 1 and disease incidence $22 \%$ and disease severity 0.4 in trial 2 when inoculum was JF196, disease incidence $20 \%$ and disease severity 0.3 in trial 1 and disease incidence $25 \%$ and disease severity 0.4 in trial 2 when infected with L7, and disease incidence 5\% and disease severity 0.1 in trial 1 and disease incidence $15 \%$ and disease severity 0.2 in trial 2 when inoculated with NF1. 'PI358001-1' had much stronger disease resistance than the resistant control 'Little Gem' and it was classified as a highly resistant lettuce (Fig. 2). This confirmed a previous observation of $\mathrm{Lu}$ et al. (2014) who reported that 'PI358001-1' was a source of high resistance. In four cases (Fig. 2), 'Little Gem' had a disease severity higher than 1.0 but lower than 2.0 , indicating it was a moderately resistant cultivar. When plants were inoculated with isolate L7, the BLS severity rates for 'Terrapin', 'Lantana', 'Okeechobee', 'Manatee', '8074', '70096', 'Gator', 'Glades', and 'Raleigh' were significantly higher than that for 'Little Gem' (Fig. 2B). These results were in agreement with those of Lu and Raid (2013). Because NF1 was a weak $X c v$ isolate, all but five lettuce genotypes ('10178', '50100', 'h1078', 'Okeechobee', and 'Terrapin') exhibited various degrees of resistance (Fig. 2C). A total of 12 genotypes (Fig. 2A) had high or moderate resistance to the Xcv isolate JF196 which had virulence between L7 and NF1. In addition to 'PI358001-1', the butterhead lettuce 'PI342512-1' was also found to have higher levels of resistance to all three $\mathrm{Xcv}$ isolates than 'Little Gem' (Fig. 2). However, the disease severities of 'PI342512-1' were lower than 1.0 in some cases and higher than 1.0 in other case. In an early study ( $\mathrm{Lu}$ et al., 2014), 'PI342512-1' was classified as a moderately resistant lettuce. Further evaluations are needed to determine whether 'PI342512-1' is a highly resistant or a moderately resistant lettuce.

All crisphead and romaine lettuces were moderately susceptible or susceptible to L7 (Table 4). Romaine lettuces were generally more susceptible to $\mathrm{L} 7$ than crisphead lettuces. However, four resistant sources were identified among the butterhead, leaf, and latin lettuce types. The results were in agreement with the BLS reactions of lettuce types to the $\mathrm{Xcv}$ isolate L7 discovered in Pernezny et al. (2000), Lu and Raid (2013), and Lu et al. (2014). According to Mikel (2007), out of the 328 lettuce cultivars which were registered in the United States from 1970 through 2004, $61.6 \%$ were crisphead, $19.5 \%$ loose leaf, $13.7 \%$ romaine, $4.9 \%$ butterhead, and $0.3 \%$ latin lettuce types. Majority of lettuce cultivars in the United States are likely to be vulnerable to the severe BLS epidemics. Therefore, new cultivars with improved resistance to BLS should be developed by incorporating resistant genes from resistant leaf, butterhead, and latin types into crisphead and romaine lettuce. On the other hand, it was demonstrated that $30 \%$ of crisphead lettuce and $23.1 \%$ of romaine lettuce were moderately resistant to $\mathrm{Xcv}$ isolate JF196, and even higher percent of these two types showed resistance to $X c v$ isolate NF1 (Table 4), indicating that plants responds differently to different $X c v$ isolates. We found that some commercial cultivars such as Gator and Glades had low disease severities under 
A JF196 $\quad$ aTrial 1 $\square$ Trial2

Trial $1 \mathrm{LSD}_{0.05}=27.6 \%$; Trial $2 \mathrm{LSD}_{0.05}=42.3 \%$
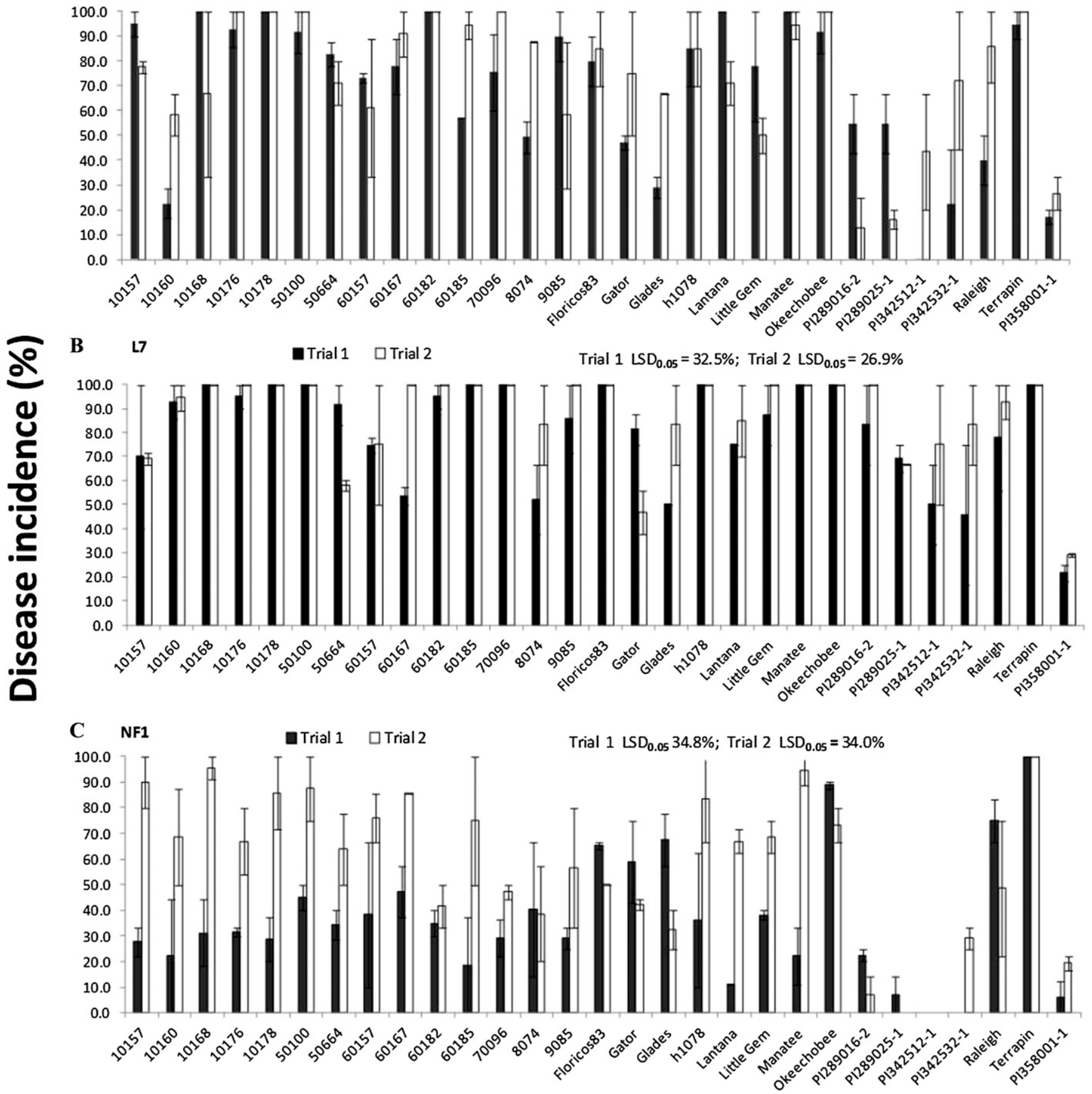

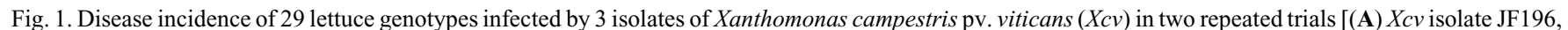

(B) $X c v$ isolate L7, and (C) Xcv isolate NF1]. The solid line on each bar is the standard deviation.

infections of the two less virulent isolates NF1 and JF196 (Fig. 2A and C). It is thus possible to identify commercial cultivars that are resistant to multiple $\mathrm{Xcv}$ strains with lower virulence. Growing such cultivars in the areas where BLS is frequently a problem can provide sufficient protection of the crop in most of years because in those years the $X c v$ strains present in the fields are less virulent.

Strategies of resistant cultivar development. The goal of breeding BLS-resistant lettuce cultivars is to develop cultivars with high level resistance that can protect lettuce from damage by $X c v$ strains that are highly virulent. The germplasm line 'PI358001-1', which is a leaf lettuce, had low disease incidences and disease severities under infection of any of the three $X c v$ isolates (Figs. 1 and 2). These observations were consistent with a previous report by $\mathrm{Lu}$ et al. (2014). All results indicate that this line has high level resistance and the resistance is stable across $X c v$ strains. It appears that the line is a good source for development of resistant cultivars. The butterhead lettuce 'PI342512-1' had diverse responses to $\mathrm{Xcv}$ isolates, exhibiting high resistance in some experiments but moderate resistance in others in this study and a previous study ( $\mathrm{Lu}$ et al., 2014). Another butterhead lettuce 'PI342532' performed similarly as 'PI342512-1' in reaction to $X c v$ isolates. It is not known whether a single one of the two butterhead lettuces can be used to develop resistant cultivars that will provide sufficient protection of the crop under severe BLS epidemic conditions. The resistant control 'Little Gem' has been found to be moderately resistant based on disease severities in many studies (Bull et al., 2007; Lu et al., 2014; Lu and Raid, 2013). In the present study, it was moderately resistant to all three $X c v$ isolates and its resistance was stable across the isolates (Fig. 2). Like the two resistant butterheads, 

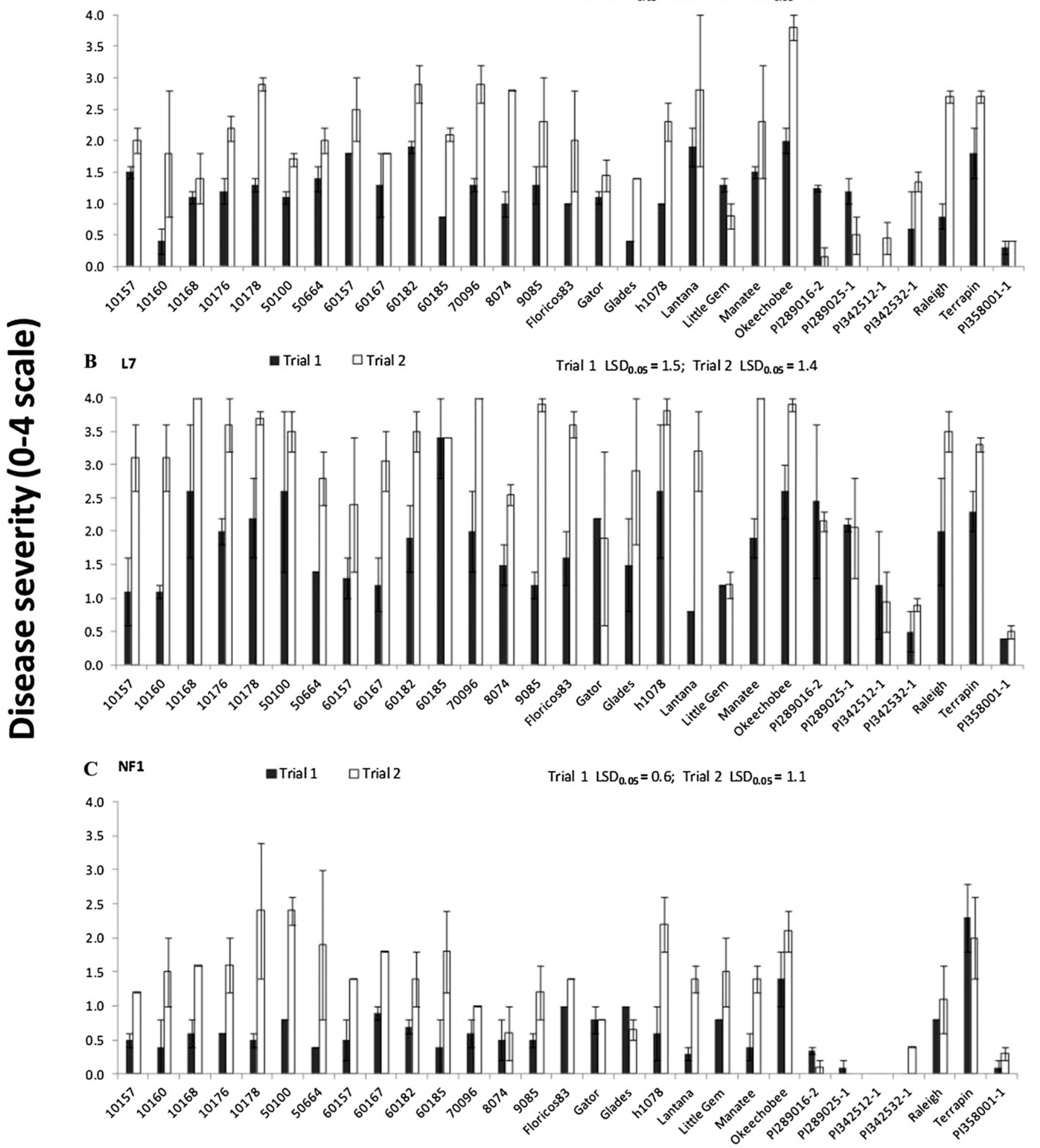

Fig. 2. Disease severity of 29 lettuce genotypes infected by 3 isolates of Xanthomonas campestris pv. viticans (Xcv) in two repeated trials [(A) Xcv isolate JF196, (B) $X c v$ isolate L7, and (C) Xcv isolate NF1]. Disease severity was evaluated using the rating system as described in Bull et al. (2007) with modifications: $0=$ no symptoms on a plant; $1=1-10$ lesions of less than $3 \mathrm{~mm} ; 2=$ more than 10 lesions of less than $3 \mathrm{~mm} ; 3=$ lesions of greater than $3 \mathrm{~mm}$; and $4=$ coalesced lesions. The solid line on each bar is the standard deviation.

damage will occur under BLS epidemic conditions if resistance in 'Little Gem' is used for protection of the crop.

Because high resistance with disease severity less than 1.0 on the $0-4$ scale in single lettuce genotypes is uncommon, other breeding strategies should be considered. In a recent paper, Hayes et al. (2014) reported that the BLS-resistance in lettuce cultivar $\mathrm{La}$ Brillante was controlled by a single gene named Xarl on linkage group (chromosome) 2 and resistance in cultivars Pavane and Little Gem was likely controlled by the same gene. There were evidences showing that chromosome 2 may carry gene(s) for BLS-resistance in many germplasm lines that were evaluated by $\mathrm{Lu}$ et al. (2014). Lu et al. (2014) also found that chromosome 4 may harbor gene(s) for high level resistance in 'PI358001-1'. If future research identifies different genes on chromosome 2 for resistances 
Table 4. Reactions of lettuce horticultural types to 3 isolates of Xanthomonas campestris pv. viticans.

\begin{tabular}{|c|c|c|c|c|c|c|c|c|c|c|c|c|c|}
\hline \multirow[b]{2}{*}{ Lettuce type } & \multirow[b]{2}{*}{ No. } & \multicolumn{4}{|c|}{ JF196z } & \multicolumn{4}{|c|}{ L7 } & \multicolumn{4}{|c|}{ NF1 } \\
\hline & & $\mathrm{HR}^{\mathrm{y}}$ & MR & MS & $\overline{\mathrm{S}}$ & HR & MR & MS & $\bar{S}$ & HR & MR & MS & $\overline{\mathrm{S}}$ \\
\hline Crisphead & 10 & 0 & 3 & 7 & 0 & 0 & 0 & 4 & 6 & 2 & 7 & 1 & $\overline{0}$ \\
\hline Romaine & 13 & 0 & 3 & 9 & 1 & 0 & 0 & 1 & 12 & 0 & 9 & 4 & 0 \\
\hline Butterhead & 3 & 1 & 2 & 0 & 0 & 0 & 2 & 1 & 0 & 3 & 0 & 0 & 0 \\
\hline Leaf & 2 & 1 & 1 & 0 & 0 & 1 & 0 & 1 & 0 & 2 & 0 & 0 & 0 \\
\hline Latin & 1 & 0 & 1 & 0 & 0 & 0 & 1 & 0 & 0 & 0 & 1 & 0 & 0 \\
\hline Total & 29 & 2 & 10 & 16 & 1 & 1 & 3 & 7 & 18 & 7 & 17 & 5 & 0 \\
\hline
\end{tabular}

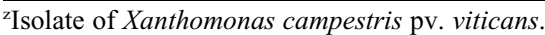

${ }^{\mathrm{y}} \mathrm{HR}=$ highly resistant; $\mathrm{MR}=$ moderately resistant; $\mathrm{MS}=$ moderately susceptible; $\mathrm{S}=$ susceptible.

in different lettuce cultivars or germplasm lines, gene pyramiding approach can be used for development of high resistant cultivars. Likewise, if the resistance in 'PI358001-1' is indeed conferred by gene(s) on chromosome 4 , lettuce cultivars with even higher resistance can be developed by combining the resistant gene(s) on chromosomes 2 and 4 into a single cultivar background.

\section{Literature Cited}

Barak, J.D. and R.L. Gilbertson. 2003. Genetic diversity of Xanthomonas campestris pv. vitians, the causal agent of bacterial leaf spot of lettuce. Bacteriology 93:596-603.

Barak, J.D., S.T. Koike, and R.L. Gilbertson. 2001. Role of crop debris and weeds in the epidemiology of bacterial leaf spot of lettuce in California. Plant Dis. 85:169-178.

Brown, Z.A. 1918. Some bacterial diseases of lettuce. J. Agr. Res. 13:367-388.

Bull, C.T., R. Hayes, L.V. Madden, S.T. Koike, and E. Ryder. 2007. Genetic diversity of lettuce for resistance to bacterial leaf spot caused by Xanthomonas campestris pv. vitians. Online. Plant Health Prog. doi: 10.1094/PHP-2007-0917-02-RS.

Bull, C.T. and S.T. Koike. 2005. Evaluating the efficacy of commercial products for management of bacterial leaf spot on lettuce. Online. Plant Health Prog. doi: 10.1094/PHP-20051121-01-RS

Carisse, O., A. Ouimet, and V. Toussaint. 2000. Evaluation of the effect of seed treatments, bactericides, and cultivars on bacterial leaf spot of lettuce caused by Xanthomonas campestris pv. vitians. Plant Dis. 84:295-299.

Fayette, J. 2014. The epidemiology, specific detection, genetic variability, and control of Xanthomonas campestris pv. Vitians, causal agent of bacterial leaf spot of lettuce. University of Florida, PhD Diss.

Glaser, L., G. Lucier, and G. Thompson. 2001. Lettuce: In and out of the bag. Economic Research Service/USDA Agricultural Outlook, p. 10-13.

Guzman, V.L. 1984. South Bay and Raleigh, two crisphead lettuce cultivars resistant to corky root rot for organic soils. University of Florida Institute of Food and Agricultural Sciences. S-310.

Guzman, V.L. and T.A. Zitter. 1983. Floricos 83: A cos lettuce cultivar resistant to two viruses, for Florida organic soils. University of Florida Institute of Food and Agricultural Sciences. S-305.

Hayes, R.J., M.A. Trent, M.J. Truco, R. Antonise, R.W. Michelmore, and C.T. Bull. 2014. The inheritance of resistance to bacterial leaf spot of lettuce caused by Xanthomonas campestris pv. vitians in three lettuce cultivars. Nat Hort. Res. 25 Feb. 2015. <http://www.nature. com/articles/hortres201466>.

Koike, S.T. and R.L. Gilbertson. 1997. Bacterial leaf spot, p. 27-28. In: Davis, R.M., K.V. Subbarao, R.N. Raid, and E.A. Kurtz (eds.). Compendium of lettuce diseases. American Phytopathological Society, St. Paul, MN.

Kousik, C.S. and D.F. Ritchie. 1996. Race shift in Xanthomonas campestris pv. vesicatoria within a season in field-grown pepper. Phytopathology 86:952-958.

Leben, C., G.C. Daft, and A.F. Schmetthenner. 1968. Bacterial blight of soybeans: Population levels of Pseudomonas glycinea in relation to symptom development. Phytopathology 58:1143-1146.

Lu, H., J. Hu, and S.J. Kwon. 2014. Association analysis of bacterial leaf spot resistance and SNP markers derived from expressed sequence tags (ESTs) in lettuce (Lactuca sativa L.). Mol. Breed. 34:997-1006.

Lu, H. and R.N. Raid. 2013. A novel screening method for evaluation of lettuce germplasm for bacterial leaf spot resistance. HortScience 48:171-174

Mikel, M.A. 2007. Genealogy of contemporary north American lettuce. HortScience 42: 489-493.

Pernezny, K., R.N. Raid, and J. Collins. 2000. Cultivar resistance and seed treatment for management of bacterial leaf spot of lettuce. Belle Glade EREC Research Report-EV2000-2.
Pernezny, K., R.N. Raid, R.E. Stall, N.C. Hodge, and J. Collins. 1995. An outbreak of bacterial spot of lettuce in Florida caused by Xanthomonas campestris pv. vitians. Plant Dis. 79:359-360.

Restrepo, S., C.M. Velez, M.C. Duque, and V. Verdier. 2004. Genetic structure and population dynamics of Xanthomonas axonopodis pv. manihotis in Colombia from 1995 to 1999. Appl. Environ. Microbiol. 70:255-261.

Robinson, P.E., J.B. Jones, and K. Pernezny. 2006. Bacterial leaf spot of lettuce: Relationship of temperature to infection and potential host range of Xanthomonas campestris pv. vitians. Plant Dis. 90:465-470

Sahin, F., P.A. Abbasi, M.L. Ivey, J. Zhang, and S.A. Miller. 2003. Diversity among strains of Xanthomonas campestris pv. vitians from lettuce. Phytopathology 93:64-70.

Sahin, F. and S.A. Miller. 1997. Identification of the bacterial leaf spot pathogen of lettuce, Xanthomonas campestris pv. vitians, in Ohio, and assessment of cultivar resistance and seed treatment. Plant Dis. 81:1443-1446.

Scortichini, M. 2005. The population structure of some plant pathogenic bacteria: An ecological and adaptive perspective. J. Plant Pathol. 87:5-12.

Toussaint, V. 1999. Bacterial leaf spot, a new disease of lettuce in Quebec caused by Xanthomonas campestris pv. vitians. Phytoprotection 80:121-125.

Tsuchiya, Y., K. Ohata, K. Azegami, and M. Matsuzaki. 1981. Pathogenicity of Xanthomonas campestris pv. vitians to various crops and weeds. Bull. Nation Inst. Agr. Sci. 35:57-66.

Umesh, K.C., S.T. Koike, and R.L. Gilbertson. 1996. Association of Xanthomonas campestris pv. vitians with lettuce seed. Phytopathology 86:S3 (abstr.)

USDA. 2014. Quick stats of lettuce. 25 Feb. 2015. $<$ http://quickstats.nass.usda.gov/results/8BD509034857-3C5F-8161-626BAB3F03A7>.

USDA. 2015a. Plant variety protection databaseGRIN. 25 Feb. 2015. <http://www.ars-grin.gov/ cgi-bin/npgs/html/pvplist.pl $>$.

USDA. 2015b. Vegetable Cultivar Descriptions for North America. $25 \mathrm{Feb}$. 2015. <http:// cuke.hort.ncsu.edu/cucurbit/wehner/vegcult/ lettucemz.html>.

USDA. 2015c. National germplasm resources. 25 Feb. 2015. <http://www.ars.usda.gov/main/ site_main.htm?modecode $=80-42-05-45>$

Vauterin, L., P. Yang, A. Alvarez, Y. Takikawa, D. Roth, A. Vidaver, R. Stall, K. Kersters, and J. Swings. 1996. Identification of non-pathogenic Xanthomonas strains associated with plants. Syst. Appl. Microbiol. 19:96-105. 